\title{
DRIVETRAIN NOISE OF THE GYROPLANE I-28
}

\author{
Sławomir Cieślak, Wiesław Krzymień \\ Institute of Aviation \\ al. Krakowska 110/114, 02-256 Warsaw, Poland \\ slawomir.cieslak@ilot.edu.pl,wieslaw.krzymien@ilot.edu.pl
}

\section{Abstract}

Gyroplanes, as ultralight aircraft, are popular transport vehicles recently. Ultralight aircraft flights take place at a low altitude - their noise is not without effect on people and nature. The localization of the sources of noise and a possibility to decrease the noise of an gyroplane are described in this paper. The rules of design and exploitation of gyroplanes do not define the limits of emitted noise.

Gyroplanes are not noisy aircraft vehicles but for their silencing the knowledge about the sources and frequency range of noise is necessary. The goal of the conducted measurement was to determine the gyroplane noise properties and the noise measurement methods. The evaluation of the noise sources was made by acoustic beamforming and the directional emission with single microphones at various engine speeds.

The supplement of these tests should be the rotor noise measurement but that investigation should be performed on a special stand, on which the rotor propulsion noise would not disturb the measurement.

Keywords: gyroplane, noise, acoustic camera, beamforming, propeller noise.

\section{INTRODUCTION}

Gyroplanes have been known for years, however their growing popularity means that the noise can become increasingly disruptive, although not as much as, for example, cars.

Noise emission is one of the most important features of an aircraft, because the noise generated by the components of the object affect the construction and the environment or the persons inside the aircraft and in the immediate surroundings (the pilot, passengers, service, observers) as well as animals. The main sources of noise in an gyroplane are: the engine, the propeller and the main rotor.

Gyroplanes are built in two basic construction types: the elder (classic) with tractor airscrew and a new (currently the most popular) with pusher airscrew. The I-28 gyroplane, designed and manufactured in ILot, has the towing propeller, but unlike the classic design the engine is placed behind the cockpit. The acoustic measurements of such a design allow for the separation of the sources of noise: the engine from the propeller [1].

In the class of ultralight aircraft, gyroplanes are just as noisy as airplanes but less than helicopters. Measurements of noise of aircraft in flight are defined by the air standards whose purpose is to reduce 
the impact on the environment during take off/landing and flight at a low altitude - they are to be requested on certification of the finished product $[2,10]$.

The following research was done to determine the sources of the noise of an gyroplane, their properties and the distribution of the acoustic pressure around the object, and during its work on earth. The frequencies logged and analyzed include frequencies in the acoustic range of the measuring equipment [3].

The measurements carried out aimed to:

- determine noise sources,

- determine the frequency bands of the emitted sounds,

- determine changes in the noise emitted for different engine speeds.

The gyroplane rotors do not have propulsion, and the prerotation, that is the initial rotor spin, does not achieve the speeds corresponding to the start, cruising or maximum speeds [4]. Measurements of the noise produced by the gyroplane rotor should be carried out separately - on a special stand.

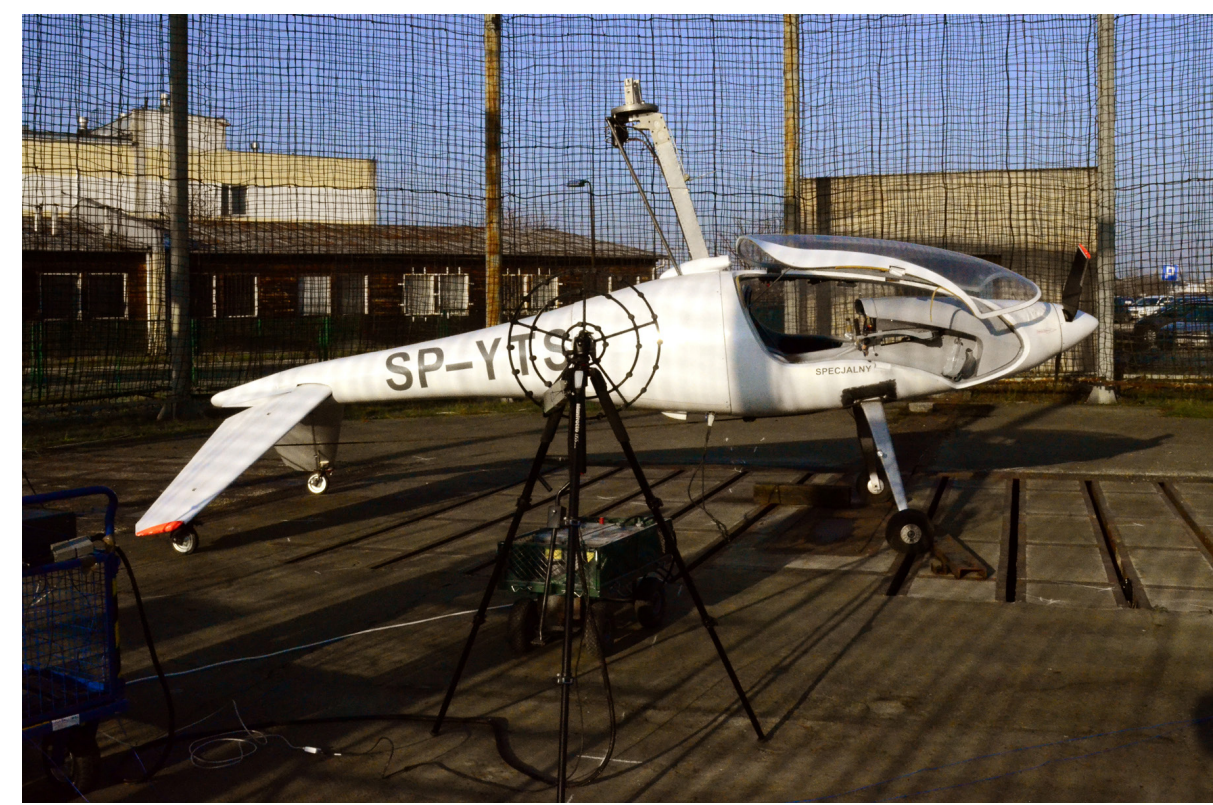

Fig. 1. Gyroplane I-28 during noise emission measurement [W. Krzymień, 2016]

\section{INVESTIGATION OBJECT AND MEASURING EQUIPMENT}

The object of the research was the I-28 gyroplane, designed and constructed at the Institute of Aviation (Fig. 1).

The gyroplane was designed as a two-seat, $6 \mathrm{~m}$-long fuselage, with a $110 \mathrm{~kW}$ diesel engine and an propeller with a diameter of $1.73 \mathrm{~m}$.

For measurements the gyroplane was placed in an open area on a concrete base and anchored by a rope. The cockpit doors during the measurements were closed, the tank half-filled with fuel. The gyroplane was prepared for normal use but without the rotor blades. The measurements were performed with one pilot on board. The tests were conducted at different engine speeds. 
Acoustic beamforming measurements were made using a circular array with 36 microphones and the LMS Test.Lab HD Acoustic Camera software [5, 6, 7].

The analysis of the signal was done on records ranging from a few to over ten seconds. Measurements were carried out for a fixed rotational speed and also for variable (increasing or decreasing) engine speed, allowing spectral analysis of the noise emitted and establishing the resonance frequencies of the sound sources.

\section{DIRECTIONAL NOISE EMISSION MEASUREMENT}

For directional noise emission measurements, the microphones were positioned around the gyroplane at a height of $1.5 \mathrm{~m}$ above the ground level: one in the gyroplane axis and others at $45^{\circ}$ to the left and to the right each, at a distance of $5 \mathrm{~m}$ from the center of the object (Fig. 1). Due to the strong slipstream, the back measurement was made with two microphones (left and right) outside the stream.

Figure 2 shows the results of the measurements as graphs of the acoustic pressure around the gyroplane for several engine speed values. The direction of $0^{\circ}$ is the direction of the flight and the figure corresponds to the view from the top of the gyroplane. The measure and the results was made with filter A (linear correction). A slight increase in sound pressure in the direction of $205^{\circ}-225^{\circ}$ is related to the noise of the exhaust pipe, which in the gyroplane is located at this point and is directed to the left.

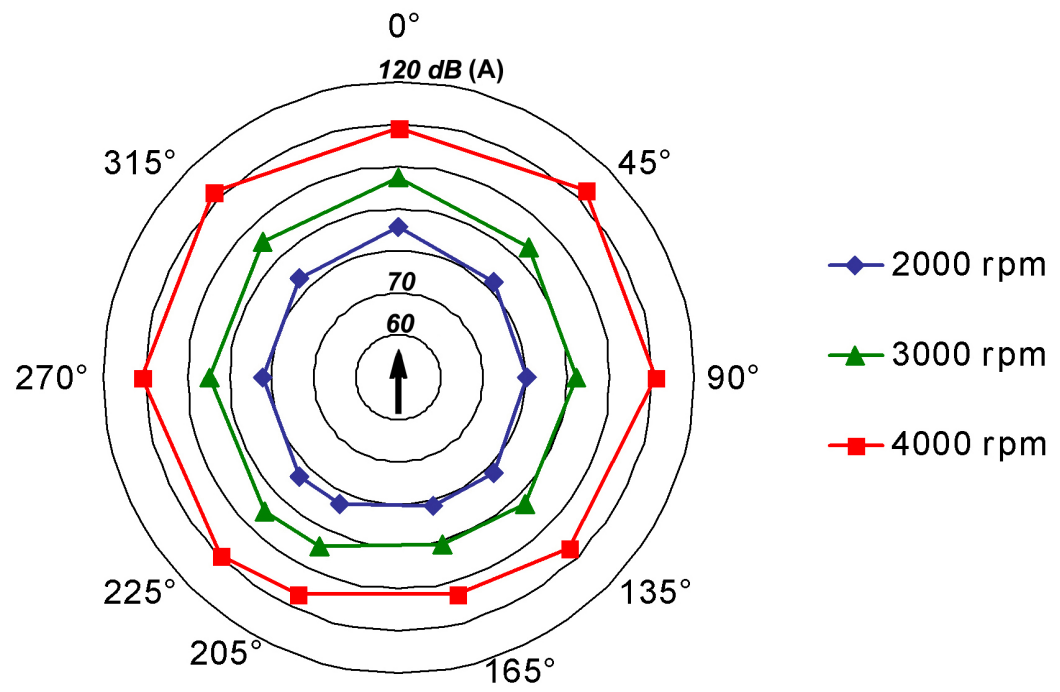

Fig. 2. Polar diagram of noise emission by the gyroplane for different speeds of the engine [W. Krzymień, 2016]

\section{THE GYROPLANE NOISE SOURCES}

On the basis of the signals measured by the acoustic camera (Fig. 1), an acoustic beamforming image was prepared for different propeller speeds. Fig. 3 shows a frequency analysis graph in a 1/3-octave format of the recorded noise for maximum propeller rotation, and Figs. 4, 5 and 6 show area graphs of the sound sources against backgrounds of gyroplane photos (for the frequency range up to $4000 \mathrm{~Hz}$ ). 


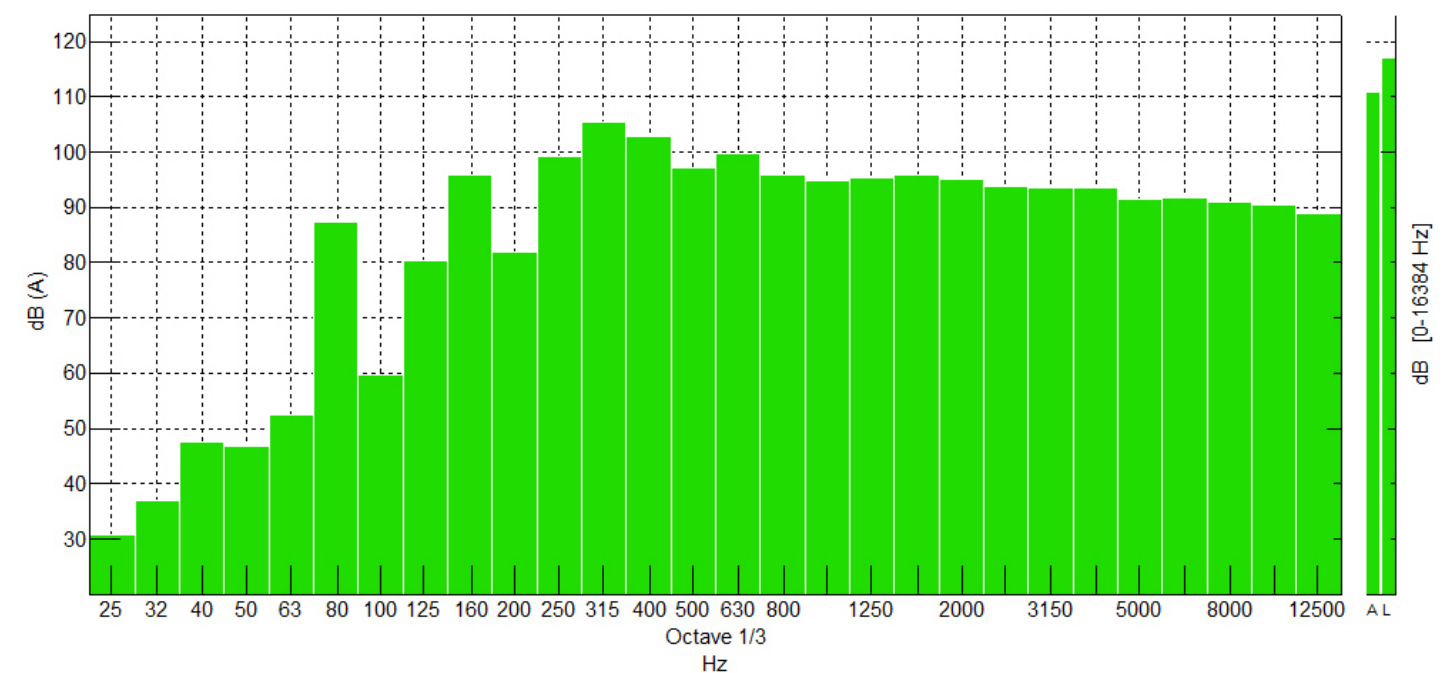

Fig. 3. Amplitude-frequency diagram in a 1/3 octave format of the measured noise [S. Cieślak, 2016]
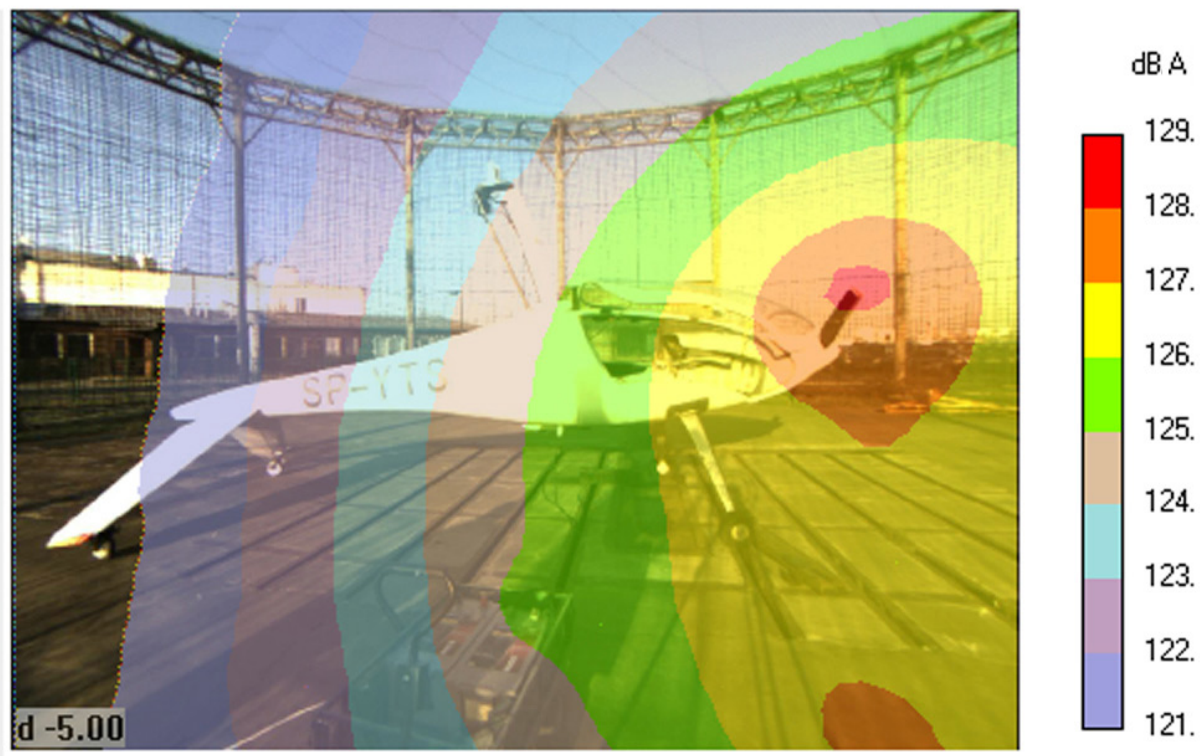

Fig. 4. Noise source distribution of the gyroplane - on the right side [S. Cieślak, 2016] 


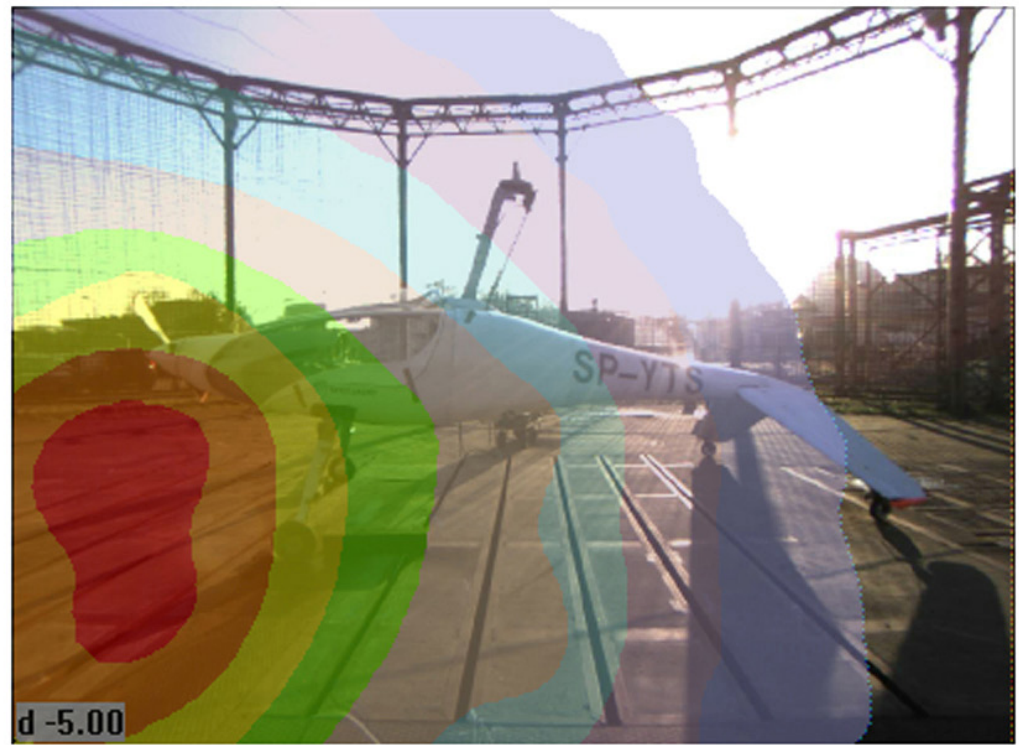

$\mathrm{dBA}$

129

128.

127.

126 .

125.

124.

123.

122

121.

Fig. 5. Noise source distribution of the gyroplane - on the left side [S. Cieślak, 2016]

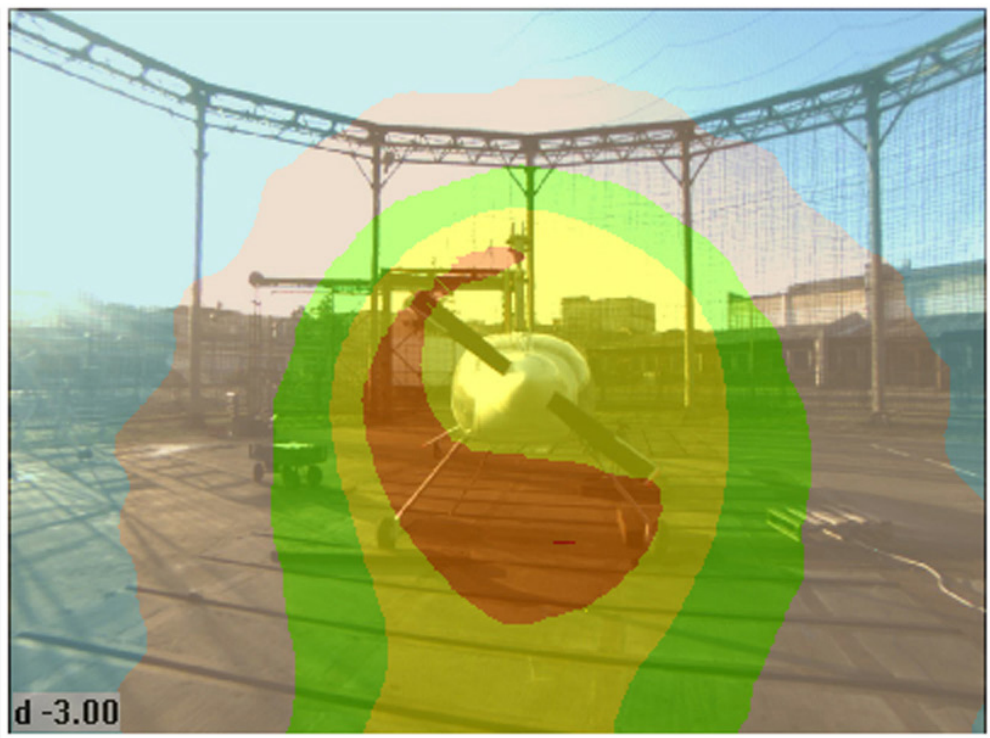

$\mathrm{dBA}$

129.

128.

127.

126.

125.

124.

123.

122.

121.

Fig. 6. Noise source distribution of the gyroplane - in front [S. Cieślak, 2016]

At lower rotational speeds, the distribution image of the gyroplane noise was very similar - the propeller was the loudest source of noise, many times larger than the engine.

The acoustic beamforming images show a strong impact of the sound waves reflected from the concrete surface on which the gyroplane was positioned [8]. 


\section{NOISE DURING ENGINE SPEED CHANGE}

On the basis of the recording of the signal from the microphone standing on the left side of the gyroplane, a graph of the rotational speed of the propeller and the corresponding sound pressure graph were drawn for the various rotational speeds of the engine - Figure 7. Changes in engine rotation speed resulted in no significant increases in sound pressure indicating the occurrence of resonance vibrations, which was the subject of separate analyses [9].
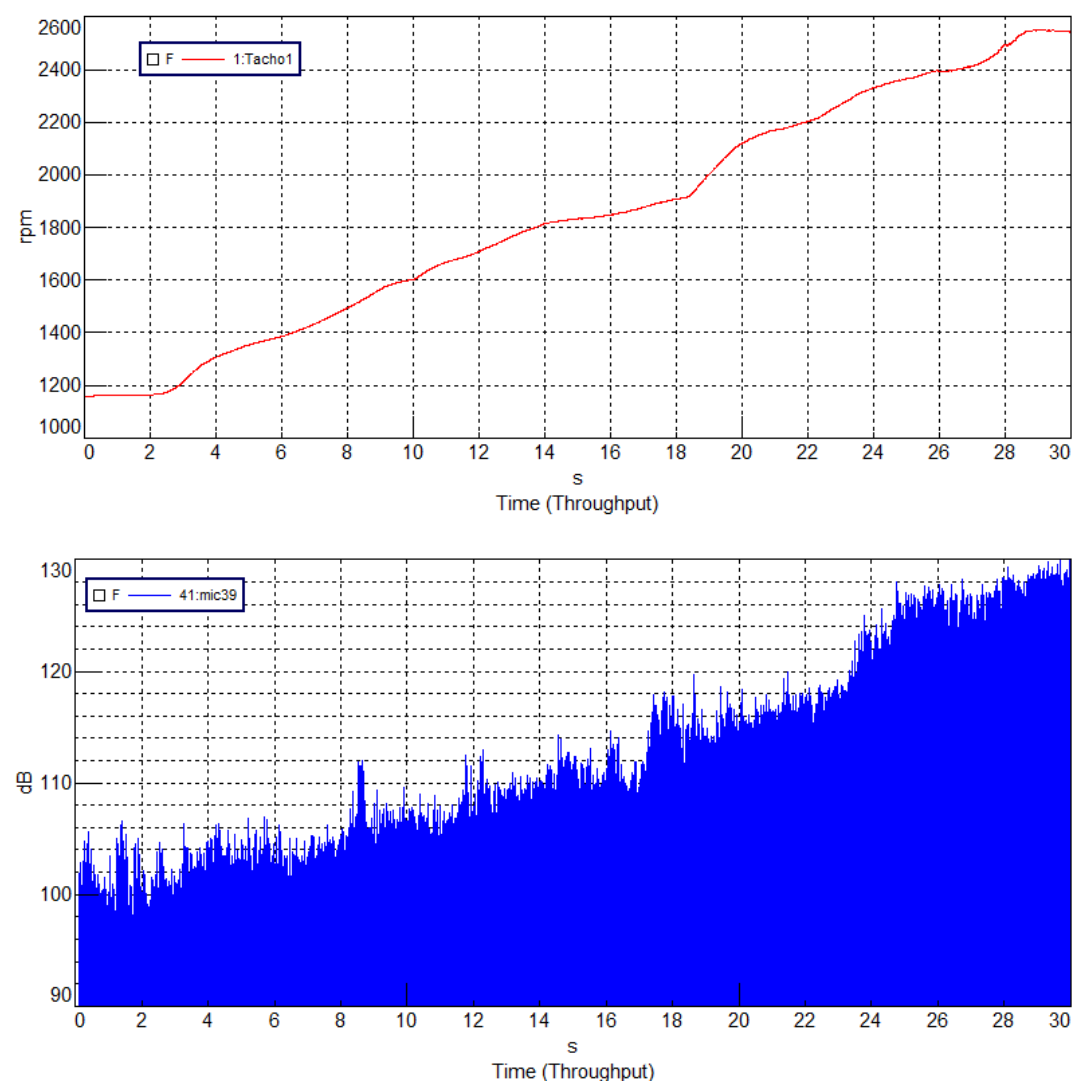

Fig. 7. Diagrams of the changes of the propeller speed and the changes in acoustic pressure measured from the left side of the gyroplane [S. Cieślak, 2016]

\section{NOISE IN THE COCKPIT}

In order to determine the sources of noise in the cockpit, the acoustic camera was placed in between the pilot seats (Fig. 8.), recording the sound distribution for different engine speeds. This image did not change and the source of the noise was the propeller and turbulence of the propeller stream. The image of sound sources in the cockpit at the maximum rotation speed is shown in Figure 9. 


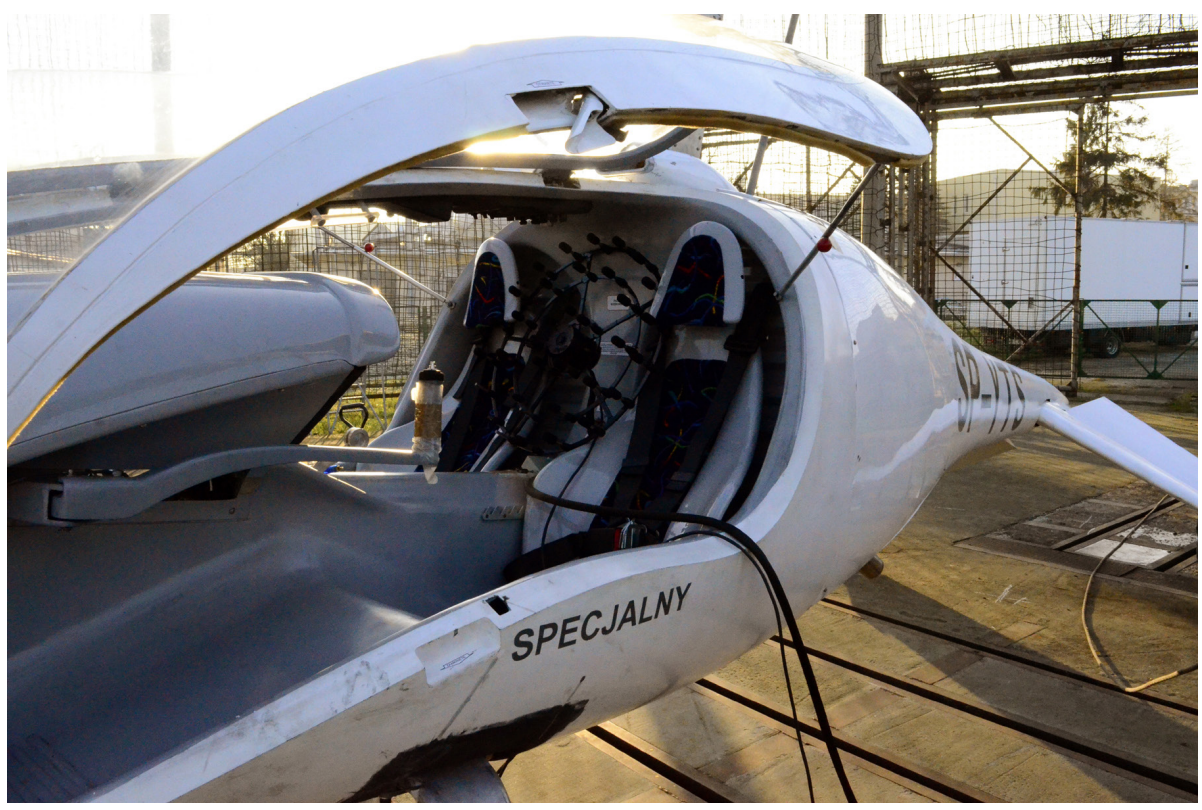

Fig. 8. Acoustic camera set in the gyroplane cockpit [W. Krzymień, 2016]

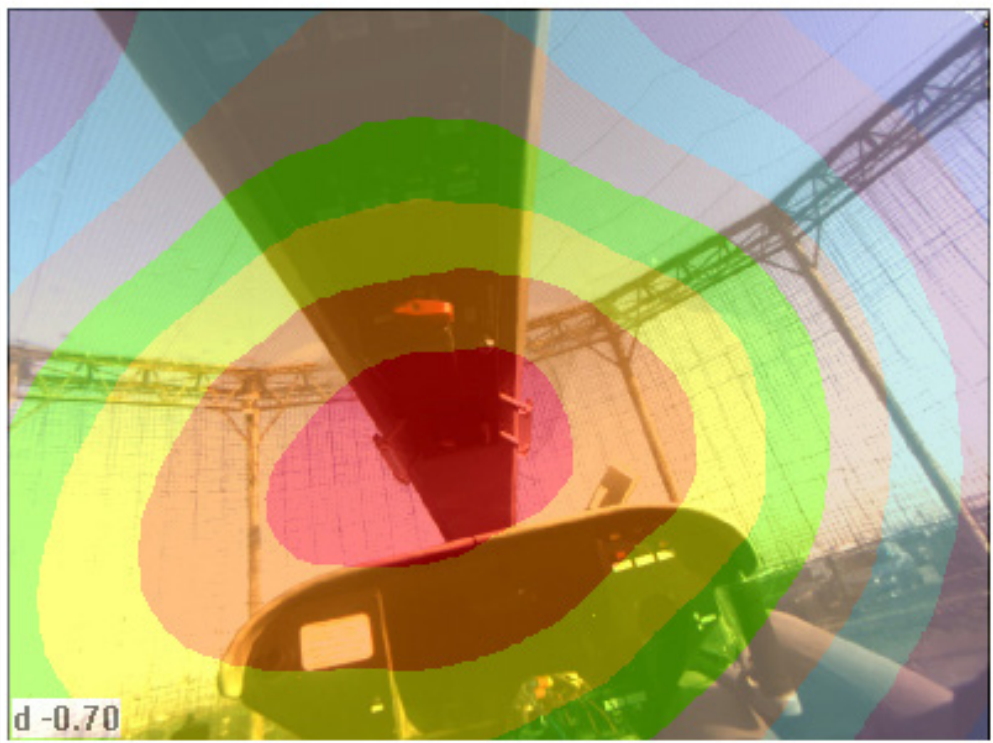

$\mathrm{dB} A$

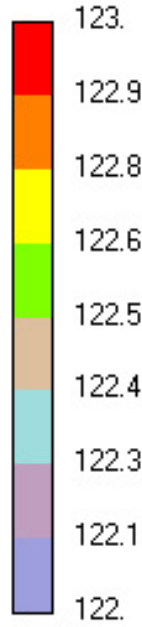

Fig. 9. Noise source distribution in the cockpit of gyroplane [S. Cieślak, 2016]

For maximum engine speed, acoustic pressure measurements were also made using a microphone located near the pilot's head. Figure 10. shows the amplitude-frequency characteristics in a 1/3-octave format based on the A-weighting curve characteristic of the human ear. The chart can be used to assess the level of noise the pilot is exposed to during the flight and to select appropriate hearing protection. 


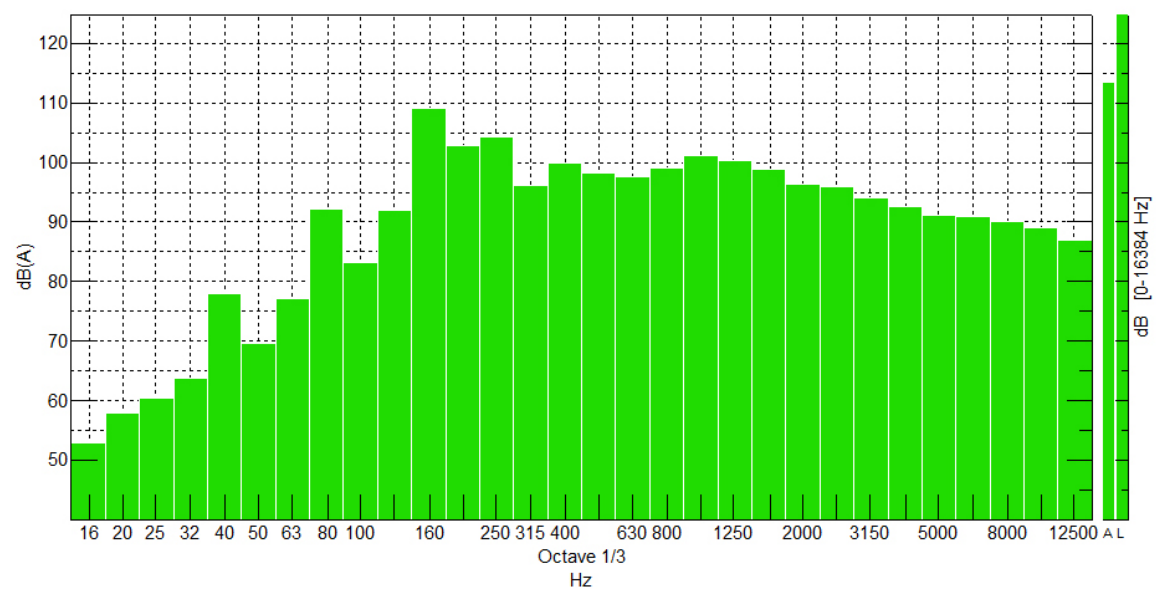

Fig. 10. Amplitude-frequency diagram in a 1/3 octave format of the acoustic pressure in the cockpit [S. Cieślak, 2016]

\section{NOISE EMITTED BY THE MAIN ROTOR}

The main rotor of the gyroplane does not have any drive other than the prerotation motor. Typically, prerotation achieves approximately $40 \%$ of the rotational speed of the rotor at the cruising speed. The rotor noise test must be carried out on a special stand whose drive is muted. Helicopter rotor noise is measured at maximum rotational speed and maximum attack angles. The gyro rotors are not twisted and do not reach such high rotation speed and have a steady angle of attack corresponding to optimum autorotation. A preliminary test of the rotor blades noise was performed with the acoustic camera set up under the rotor to determine the noise. Fig. 11 shows an image of the rotor noise sources in acoustic beamforming analysis. method. Research has also shown that, in the case of a gyro rotor, the noise is generated at the blade ends and is considerably smaller than that of the propeller.

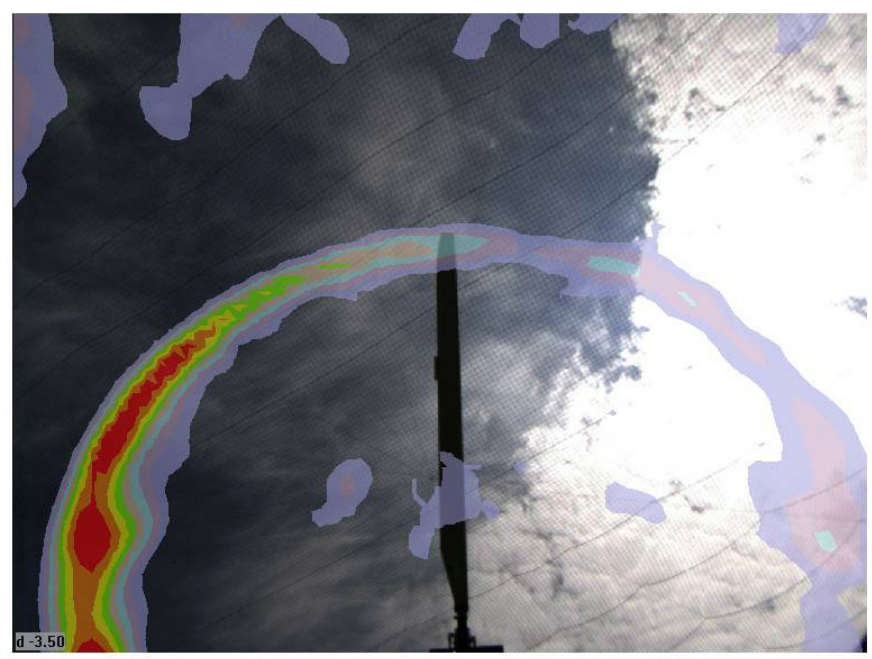

$\mathrm{dBA}$

Fig. 11. Noise source distribution of the main rotor blade [S. Cieślak, 2016] 


\section{CONCLUSIONS}

1. The noise emitted by the gyroplane in the forward direction (Fig. 2) is not significantly higher than in the lateral or back direction. The sound pressure difference on the left and right is about 2-3 dB.

2. The propeller, especially its tips, is the main source of noise emitted by the gyroplane.

3. Propeller noise depends on its rotational speed. The reduction of the noise level can therefore be achieved by reducing the rotational speed or the shape of the blades.

4. The acoustic beamforming method used makes it possible to locate the source of the sound, and in the case of construction modifications aiming to reduce the noise, it will be an appropriate tool for assessing the effectiveness of the work performed.

5. During changes in the rotational speed of the engine, there are no significant resonances increasing the noise emitted by the gyroplane.

6. The maximum level of the A-weighted acoustic pressure in the cockpit, A-weighted and measured in $1 / 3$ octave bands, shows center frequencies of $160,200,250 \mathrm{~Hz}$, for which values it exceeds $102 \mathrm{~dB}(\mathrm{~A})$. The crew should be equipped with hearing protection sufficiently dampening the specified frequencies.

7. The rotor noise tests should be carried out on a separate, quiet stand. The results of the preliminary measurements show that its noise is less than the noise of the propeller. The presented method of measurement is useful for research on new blades with low noise emission.

\section{BIBLIOGRAPHY}

[1] Rudiuk A. et al., 1988, „Develop new methods of noise measurement in airplanes cocpits” (in Polish: „Opracowanie nowych metod pomiarów hałasu w kabinach statków powietrznych”), IoA Report No GE-134, Warsaw.

[2] Mnitowski S., 2002, „Sources of helicopters noise” (in Polish: „Źródła hałasu wytwarzanego przez śmigłowiec”), Transactions of the Institute of Aviation, No. 168-169, pp. 97-103.

[3] Cempel Cz., 1989, „Vibroacoustic diagnostic of machines” (in Polish: „Diagnostyka wibroakustyczna maszyn”), Państwowe Wydawnictwa Naukowe, Warsaw.

[4] Cieślak S., 2011, „Analysis of the possibility of increasing cruise speed and reduce autogiro's noise” (in Polish: „Analiza możliwości zwiększenia prędkości przelotowej i zmniejszenia poziomu hałasu wiatrakowca"), Transactions of the Institute of Aviation, No. 219, pp. 31-38.

[5] Christensen J. J. and Hald J., 2004, "Beamforming”, Brüel\&Kjær Technical Review, No. 1-2004.

[6] Siemens PLM Software, 2014, "Acoustic Beamforming”, Technical info issued by: Siemens.

[7] Siemens PLM Software, 2014, "Acoustic Holography”, Technical info issued by: Siemens.

[8] Deblauwe F., Jansen K., Robin M., 2007, „Extending the usability of Near-Field Acoustic Holography and Beamforming by using Focalization", 14th International Congress on Sound Vibration, Cairns, Australia.

[9] Krzymień W., 2011, „Vibration properties of the gyrocopter” (in Polish: „Właściwości drganiowe wiatrakowca”), Transactions of the Institute of Aviation, No. 219, pp. 234-239.

[10] Airworthiness rules ASTM 2352-09. 


\section{HAŁAS UKŁADU NAPĘDOWEGO WITRAKOWCA I-28}

\section{Streszczenie}

Wiatrakowce jako ultralekkie statki latające stają się w ostatnich latach popularnym środkiem transportu. Loty ultralekkich statków powietrznych odbywają się na małych wysokościach - ich hałas nie pozostaje bez wpływu na ludzi i przyrodę. Lokalizacja źródeł hałasu w wiatrakowcu oraz możliwości jego ograniczenia jest przedmiotem niniejszego artykułu. Przepisy budowy i eksploatacji wiatrakowców nie definiują wymagań dotyczących emitowanego hałasu.

Wiatrakowce nie należą do najgłośniejszych środków transportu powietrznego lecz wyciszenie wymaga znajomości źródeł hałasu jak i zakresu częstotliwości. Przeprowadzono pomiary mające na celu określenie właściwości akustycznych jak i przyjęcia metodyki pomiarów akustycznych wiatrakowców. Ocenę źródeł hałasu wykonano przy pomocy tzw. akustycznego beamforming’u a rozkład emisji pojedynczymi mikrofonami przy różnych prędkościach obrotowych silnika.

Uzupełnieniem tych badań był pomiar hałasu wirnika jednak badania takie przeprowadzono na specjalnym stanowisku, by hałas napędu wirnika nie zakłócał pomiarów.

Słowa kluczowe: wiatrakowiec, hałas, kamera akustyczna, beamforming, hałas śmigła. 